\title{
The Comparison of Main Copper Sulphide Minerals Beneficiation Under Laboratory and Industrial Conditions at the KGHM Concentration Plant
}

\author{
Pawet KURZYDEO ${ }^{1)}$, Witold PAWLOS ${ }^{2)}$
}

\footnotetext{
1) University of Wrocław, Faculty of Earth Sciences and Environmental Management; email: pawel.kurzydlo@kghm.pl

2) KGHM Polska Miedź S.A., The Concentration Plant Department; email: witold.pawlos@kghm.pl
}

http://doi.org/10.29227/IM-2020-01-01

Submission date: 14-01-2020 | Review date: 02-02-2020

Abstract
The Zechstein copper ore deposit located on the Foresudetic monocline has a complex geological structure both in lithological and
mineralogical aspects. The significant variability in quantity and quality of minerals deposited in the ore bed is one of the factors
determining the susceptibility of copper ore to beneficiation based on flotation, which is carried out in the KGHM Concentration
Plant. Based on the algorithm developed, flotation experiments on a laboratory scale have been conducted to predict the upgrade rates
under industrial conditions. This paper provides the results of the mineralogical examination of the flotation products performed by
one of the KGHM Concentration process lines and compares the beneficiation of various copper sulphide minerals. The results of the
laboratory tests have been compared with the results of sampling carried out simultaneously at the process line. A procedure has been
proposed to develop equations defining the industrial upgradability curves for copper sulphide minerals under the KGHM Concen-
tration Plant conditions.

Keywords: copper sulphide minerals, flotation, upgrade curves, scale factor

1. The Effect of Lithological and Mineralogical Conditions in the Lgom Copper Ore Deposit on the Results of Ore Processing

The copper ore deposit of the Legnica-Głogów Copper District (LGOM), located on the Foresudetic Monocline and currently exploited by KGHM, is characterised by significant qualitative and quantitative variability of ore minerals. The deposit area includes white sandstone formations and the sedimentary rocks of the Zechstein cyclothem Werra (PZ1) lying above them. The accumulation of copper sulphides and accompanying metals occur in the layer of white sandstone (white Rotliegend), basic limestone (border dolomite), copper-bearing shale (clayey shale in the bottom zone, dolomitic shale in the back zone) and carbonate rocks (limestone and dolomites).

The main group containing copper sulfide minerals include chalcocite, digenite, chalcopyrite, bornite, covellite, tennantite, tetrahedrite, enargite, and the co-existing with them: galena, sphalerite, pyrite, marcasite, cuprite, native silver and many other minerals, including noble and rare metal elements: Ag, Au, Pt, Pd, Ni, Re, Se.

The studies on the genesis and geological structure of the deposit [1], [2] have revealed that in the dolomite and shale bottom the main and largest zone of chalcocite mineralization in the N-S direction may be distinguished, beside the second zone, extending to the east, where diverse minerals with the predominance of bornite occur. In sandstone, the area of ore minerals may be divided into the region of chalcocite domination in the centre of the deposit area, a diverse zone of occurrence of various ores, mainly chalcopyrite, bornite and pyrite in the eastern and northeastern part of the deposit, and the chalcopyrite-pyrite zone constituting the southwestern border of the chalcocite zone [1].
The forms of ore minerals are also diverse and largely depend on the lithological fraction. In sandstone ore, sulphides, especially chalcocite, form massive-, socket- and vein-type ore beds. In carbonate rocks and in shale, disseminated-, socketand vein-type ore beds dominate. In the dolomites, one can observe, that terrigenous material, foraminifera' skeletons, as well as carbonate cement minerals (spores, sulphates) have often been replaced by sulphides. The vein clusters found in shale often have a direction incompatible with lamination, which is associated with tectonics and the method of migration of hydrothermal solutions in shale layers. Besides, there are numerous organogenic occurrences of disseminated-, lenticular- and socket-type formations in shale resulting from the replacement of residues of living forms and places of their feeding [1].

Characteristics of the ore in terms of lithological and mineralogical structure affect the results of the flotation process carried out at the KGHM Concentration Plant. The differences in flotation potential result from the structure of copper-bearing minerals and barren components, which differ in specific lithological fractions. Shale and carbonates, where sulphide minerals in the form of small grains coexist with easily floatable barren components in the form of clay minerals and organic matter, have the lowest upgrading potential. Beneficiation of sandstone ore is the easiest process, which is associated with the optimal grain size distribution of sulphide minerals (50$200 \mu \mathrm{m}$ ) and the high susceptibility of sandstone rocks to crushing and release of ore minerals [3]. A comparison of upgradability of the specific lithology fractions may be summarized by saying that the sandstone with the worst upgradability may be upgraded easier than the shale with the best upgradability (see Fig. 1). 


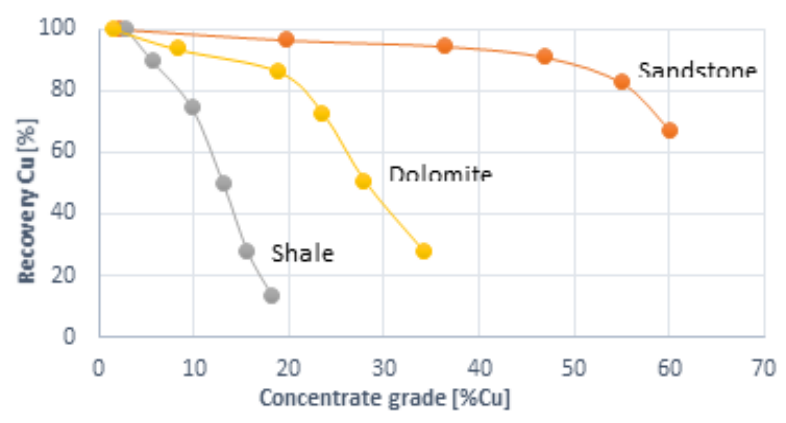

Fig. 1. The comparison of upgradability of specific lithology fractions [7] Rys. 1. Porównywanie wzbogacalności poszczególnych frakcji litologicznych [7]

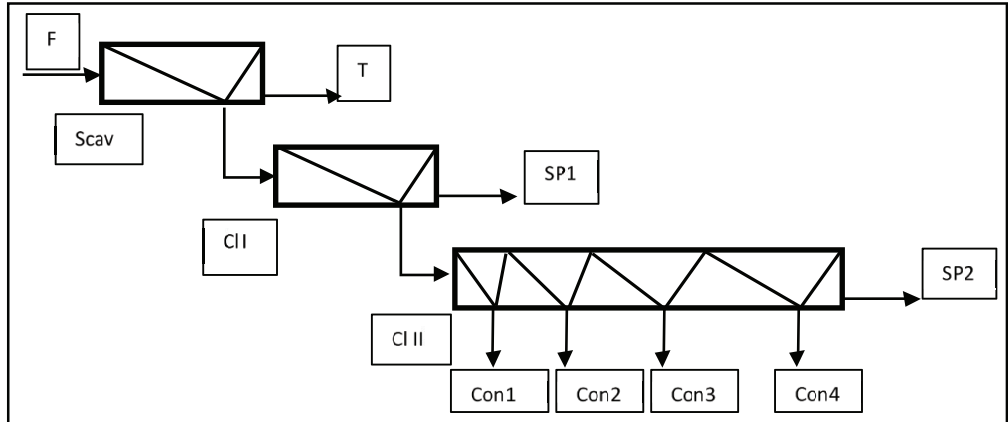

Fig. 2. Laboratory flotation flowsheet ( $\mathrm{F}$ - feed, $\mathrm{T}$ - final tailings, SP1 - semi-product after first cleaning, SP2 - semi-product after second cleaning, Con1-Con4 - the final concentrates after second cleaning)

Rys. 2. Schemat flotacji laboratoryjnych (F - nadawa, T - odpad końcowy, SP1 - półprodukt I czyszczenia, SP2 - półprodukt II czyszczenia, Con1-Con4 - koncentraty końcowe II czyszczenia)

The operation system of the KGHM mines does not allow for selective excavation of lithological fractions and transport thereof to the concentration plant. In practice, the runof-mine ore that goes to each of the three processing plants demonstrates high variability of lithological and mineralogical parameters, which depends on the currently exploited parts of the deposit. Under such conditions of the concentration process, the selection of optimal process parameters is of key importance. As examples of these parameters, one may mention flotation reagents, especially collectors. KGHM performs laboratory and industrial tests of new reagents that appear on the market as a result of dynamic progress in the chemical industry. Recent studies [4], [5] have updated the optimal mixtures of collecting reagents relevant to the changing lithological and mineralogical properties of copper ores to be processed at KGHM plants. Currently, the concentrators apply a mixture of sodium salts of alkyl xanthates with sodium dialkyldithiophosphate for ores with a diverse mineralogical cross-section occurring in beds with variable lithology and a mixture of sole xanthates for ore with a relatively high proportion of carbonate rocks, where chalcocite predominates. The selection of appropriate collecting reagents is a continuous process. The methodology used in the laboratory tests must allow for an appropriate degree of correlation with industrial results. Work on developing such a methodology should be based on the varied upgradability of copper sulphide minerals. Current techniques of mineralogical analysis (MLA, QEMSCAN) allow for using their capacities to develop a model for determining basic upgrading parameters by conversion thereof from a laboratory to an industrial scale.

\section{The Research Methodology}

In order to determine the beneficiation rates for the main copper ore minerals in laboratory conditions, the most commonly used open flotation methodology with kinetic flotation of the products of the last stage of flotation has been applied [6].

Research of industrial ore processing products was based on the determination of re-flotation of final products [7].

The samples of the feed for laboratory-scale testing were taken from one of KGHM's process lines at the Concentration Plant, during nine subsequent working shifts. In the same period, samples of tailings and the final concentrates from the examined process line were taken.

The samples were ground in a laboratory ball mill with a capacity of $2.5 \mathrm{dm}^{3}$, filled with $40 \%$ load of stainless steel balls with diameters from 10 to $30 \mathrm{~mm}$, a single milling charge consisted of $800 \mathrm{~g}$ of ore and $500 \mathrm{~cm}^{3}$ of process water taken from the examined technology line. The grinding time was 80 minutes.

The prepared samples were subjected twice to flotation experiments in an open system including the scavenger flotation (Scav) and two cleanings ( $\mathrm{Cl}$ I and $\mathrm{Cl}$ II) with fractionated flotation at the second stage of cleaning (Fig. 2).

Flotation tests were carried out in a Denver D12 mechanical flotation cell with a self-aspirating rotor, in $2.5 \mathrm{dm}^{3}$ (Scav and $\mathrm{Cl}$ I) and $1.5 \mathrm{dm}^{3}$ (Cl II) cells. The density of solids in the flotation cell at the beginning of the experiments was about $300 \mathrm{~g} / \mathrm{dm}^{3}$.

Flotation tests of industrial products consisted of onestage kinetic flotation of samples and separation of five froth products for the final concentrate and three for tailings. 


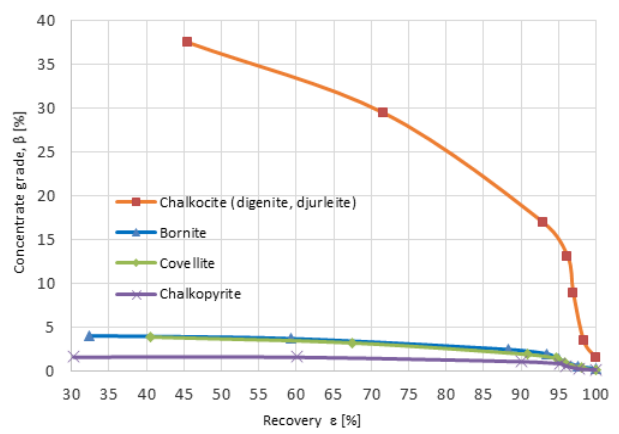

Fig. 3. The beneficiation of selected copper sulphide minerals under laboratory conditions Rys. 3. Wzbogacanie wybranych minerałów siarczkowych miedzi w warunkach laboratoryjnych

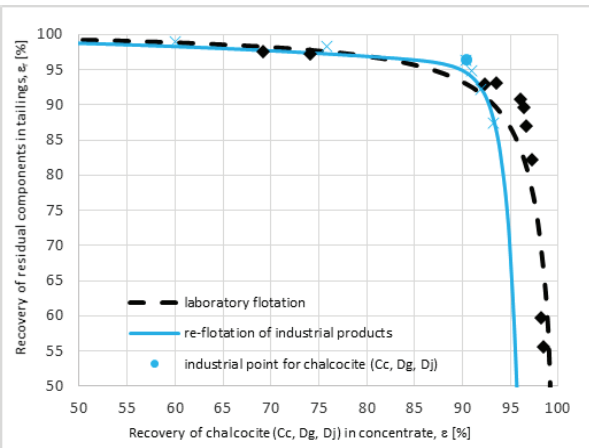

Fig. 4. The comparison of beneficiation of chalcocite with digenite and djurleite under laboratory and industrial conditions Rys. 4. Porównanie wzbogacania chalkozynu wraz z digenitem i djurleitem w warunkach laboratoryjnych i przemysłowych

For the tests, the same reagents as those used in industrial conditions were used:

- the collector: a mixture of ethyl and isobutyl sodium xanthate $(60: 40)$,

- the frother: a mixture of alkyl polyglycols.

All flotation reagents were dispensed to the flotation pulp in the form of aqueous solutions. Each of the solutions was prepared just before starting the flotation test.

During flotation of the feeds, flotation reagents were added at the beginning of the scavenger flotation, with the flotation collector dose $(80 \mathrm{~g} / \mathrm{Mg})$ separated into two parts: $60 \%$ of the reagent was added at the beginning of the flotation, and $40 \%$ after 5 minutes. The frother was added once at the beginning of the experiment at a dose of $20 \mathrm{~g} / \mathrm{Mg}$. During the flotation of the final concentrate, no flotation reagents were added to the suspension, while in the case of the final tailings, flotation was carried out in the presence of the collector only, in the amount of $5 \mathrm{~g} / \mathrm{Mg}$.

Each of the flotation products obtained was washed with distilled water to rinse the salts dissolved in the process water, the pulp was filtered subsequently on the Büchner funnel. The products were then weighed and the homogenised samples for laboratory determinations of copper content and mineral analyses using the QEMSCAM technique were prepared.

\section{Presentation Of Results}

Based on the results of mineralogical determinations, the balance characteristics of flotation experiments were com- piled for four major copper-bearing minerals: chalcocite (as the sum of chalcocite, digenite and djurleite), bornite, covellite and chalcopyrite. On their basis, upgrading curves for useful components were drawn up. In Fig. 3, the comparison of mineral upgrading under laboratory conditions on Halbich curves has been presented. The dominant content of chalcocite in the tested material is noticeable. To find a mathematical relationship between upgrading parameters under laboratory and industrial conditions, flotation balances were plotted in the coordinate $\varepsilon r=f(\varepsilon)$, which has the advantage of defining the relationship by only one parameter - the selectivity index a, which is not affected by the content of the useful ingredient in the feed.

In a search for the relationship between the laboratory and industry scales, the upgrading curves in the recovery residuals recovery coordinates were used. For the approximation of the curves $\varepsilon r=f(\varepsilon)$ different equations were used depending on the scale considered:

- for laboratory-scale tests - the equation describing the Fuerstenau curve, i.e.:

$\varepsilon_{r}=f(\varepsilon)=a \frac{100-\varepsilon}{a-\varepsilon}$

where: $\varepsilon$ - recovery of the tested mineral in the concentrate, $\varepsilon_{\mathrm{r}}$ - recovery of the residual components in the tailings, a - the selectivity index for laboratory scale

- to define the industrial upgrading curve - the modified Fuerstenau curve equation for process conditions at KGHM (asymmetrical curve [7]), i.e.: 


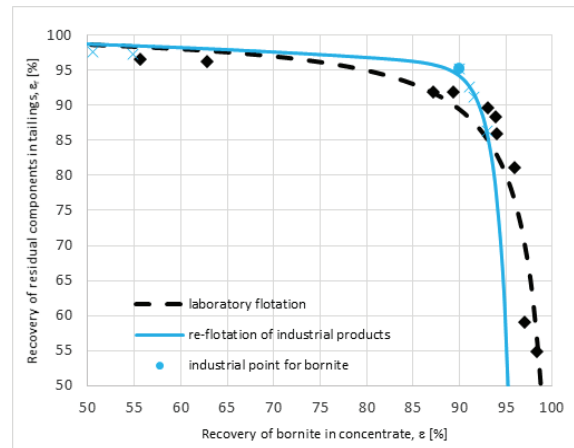

Fig. 5. The comparison of beneficiation of bornite under laboratory and industrial conditions Rys. 5. Porównanie wzbogacania bornitu w warunkach laboratoryjnych i przemysłowych

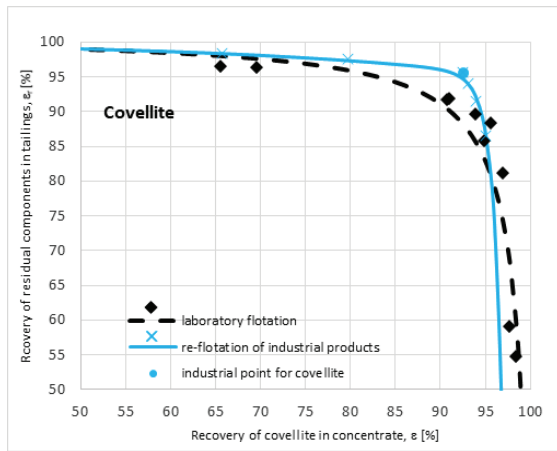

Fig. 6. The comparison of beneficiation of covellite under laboratory and industrial conditions Rys. 6. Porównanie wzbogacania kowelinu w warunkach laboratoryjnych i przemysłowych

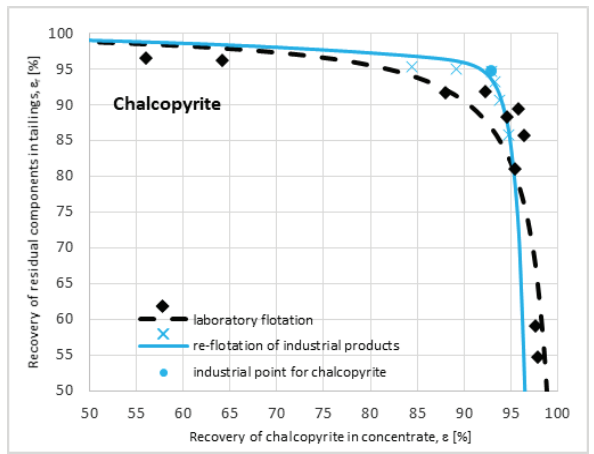

Fig. 7. The comparison of beneficiation of chalcopyrite under laboratory and industrial conditions Rys. 7. Porównanie wzbogacania chalkopirytu w warunkach laboratoryjnych i przemysłowych

$\varepsilon_{r}=f(\varepsilon)=a^{\prime} \frac{100-\varepsilon}{a^{\prime}-\varepsilon}-0.07\left(a^{\prime} \frac{100-\varepsilon}{a^{\prime}-\varepsilon}-95.5\right)^{2}\left(100-a^{\prime} \frac{100-\varepsilon}{a^{\prime}-\varepsilon}\right)$

where: a' - the selectivity index for industrial scale, other symbols as in formula (1).

Having obtained the results of laboratory flotation and flotation of industrial products determined in the course of the experiments carried out independently of each other, it should be assumed that there is an inequality $a \neq a^{\prime}$ between the selectivity indices for both considered scales. The calculation results have been presented in Fig. 4-7.

\section{Comparison of the Results Regarding Both the Laborato- ry and Industrial Scales}

Using the results of beneficiation of minerals on both the laboratory and industrial scales, it is possible to determine the relationships of indices characteristic for the considered components (scale factors).

In practical application at an industrial plant, the use of the selectivity index and the upgrade curve in the $\varepsilon r=f(\varepsilon)$ coordinates is not convenient. Having obtained laboratory results and knowing the scale factor, it is possible to simulate the anticipated upgrading of the specific mineral under industrial conditions in the coordinate system of recovery - concentrate grade. The curve may be determined provided the content of mineral in the feed $(\alpha)$ is known. The graph below presents the results for chalcocite with its content in the feed determined as $\alpha=1.51 \%$.

\section{Summary}

The prediction for industrial upgrading of copper sulphide minerals based on the results of laboratory analyses as presented in this paper involves the following sequence of events: 
Tab. 1. The comparison of selectivity indices for the laboratory and industrial scales

Tab. 1. Porównanie wartości wskaźników selektywności skali laboratoryjnej i przemysłowej

\begin{tabular}{|l|l|l|l|}
\hline \multicolumn{1}{|c|}{$\begin{array}{c}\text { Useful } \\
\text { component }\end{array}$} & \multicolumn{1}{|c|}{$\begin{array}{c}\text { the laboratory } \\
\text { index a }\end{array}$} & $\begin{array}{c}\text { the industrial } \\
\text { index } \mathbf{a}^{\prime}\end{array}$ & $\begin{array}{c}\text { Ratio } \mathbf{r}=\mathbf{a} / \mathbf{a}^{\prime} \\
\text { (the scale factor) }\end{array}$ \\
\hline Chalcocite & 100.81 & 100.58 & 1.00228 \\
\hline Bornite & 101.33 & 100.65 & 1.00686 \\
\hline Covellite & 101.09 & 100.44 & 1.00677 \\
\hline Chalcopyrite & 101.16 & 100.47 & 1.00650 \\
\hline
\end{tabular}

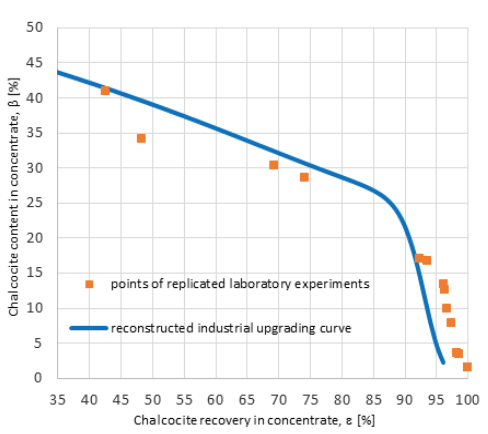

Fig. 8. The reconstruction of industrial upgrading curve of chalcocite based on laboratory results Rys. 8. Odtworzenie krzywej wzbogacania przemysłowego chalkozynu na podstawie wyników laboratoryjnych

- $\quad$ performing two laboratory flotations including the scavenger stage and two cleanings with kinetic flotation during the second cleaning, to determine the selectivity index a for the laboratory scale.

- calculating the industrial scale selectivity index: $a^{\prime}=$ $\mathrm{a} / \mathrm{r}$, where $\mathrm{r}$ is the previously determined scale factor for a given mineral,

- $\quad$ plotting the relationship in the coordinate system $\beta$ $=f(\varepsilon)$ (Halbich curve). As the curve depends on the content of a mineral in the feed $(\alpha)$, the content value known after laboratory experiments should be used. The relationship describing the Halbich curve is determined by the equation:

$\beta=f(\varepsilon, \alpha)=\frac{100 \alpha \varepsilon}{100\left(100-\varepsilon_{r}-\alpha\right)+a\left(\varepsilon+\varepsilon_{r}\right)}$

where: $\beta$ - the content of a mineral in the concentrate, $\varepsilon$ - mineral recovery, $\alpha$ - the content of a mineral in the feed, $\varepsilon_{\mathrm{r}}$ - recovery of residual minerals in tailings calculated according to the formula (2).

The tests carried out confirm the legitimacy of using the asymmetric curve to approximate the results of industrial upgrade defined as re-flotation of industrial concen- trates and final tailings. The position in the system $\varepsilon_{\mathrm{r}}=\mathrm{f}(\varepsilon)$ of industrial re-flotation points correlate with the regression curve for tested copper sulphide minerals. Due to the duplicated series of experiments on a laboratory scale carried out simultaneously with the tests of industrial products, it is possible to determine the relationship between the characteristic values of upgrading curves for both scales. Using the known scale factors, in the event of changes in the technology process, in particular when introducing new flotation reagents, it is possible to predict beneficiation of minerals under industrial conditions based on laboratory tests. The scale factors presented in this paper should be verified and their values confirmed employing subsequent tests.

The calculated scale factors allow simulation of industrial enrichment curves for specific minerals in the system $\varepsilon_{\mathrm{r}}=\mathrm{f}$ $(\varepsilon)$ as well as $\beta=f(\varepsilon)$, which is much more practical in industrial conditions. This will enable practical assessment of the effect of changes in the technology process parameters on the production results to be achieved, based only on laboratory test results. Knowing the content of individual minerals in the feed and the theoretical content of $\mathrm{Cu}$ in specific minerals, one can forecast the copper processing performance under industrial conditions. 


\section{Literatura - References}

1. Pieczonka J. 2011: Prawidłowości w rozmieszczeniu minerałów kruszcowych w złożu rud miedzi na monoklinie przedsudeckiej. Wydawnictwa AGH, Kraków

2. Kucha H., Pawlikowski M. 2010: Badania genezy cechsztyńskich złóż miedzi w Polsce. Geologia Kwartalnik Akademii Górniczo-Hutniczej im. St. Staszica w Krakowie, Vol. 36, Book 4, pp. 513-538

3. Pawlos W., Poznar E., Krzemińska M. 2017: Wpływ litologicznego zróżnicowania nadawy na wskaźniki technologiczne w Zakładach Wzbogacania Rud KGHM Polska Miedź S.A. Biuletyn Państwowego Instytutu Geologicznego, Warszawa, No. 469, pp. 67-74

4. Krzemińska M. 2017: Wpływ mieszaniny kolektorów flotacyjnych na efektywność wzbogacania rud miedzi. PhD thesis, Wrocław, not published

5. Duchnowska M., Bakalarz A., Jakubińska J., Kuroszczyk K., Karwowski P. 2018: Weryfikacja aktualnych stosowanych mieszanin zbieraczy w O/ZWR. Report on the implementation of the expert opinion, Wrocław, not published

6. Łuszczkiewicz A. and others, 2013: Opracowanie metodyki badania odczynników flotacyjnych pod kątem ich własności użytkowych. Research report, Wrocław, not published

7. Tumidajski T., Łuszczkiewicz A., Drzymała J., Trybalski K., Foszcz D., Muszer A., Niedoba T., Saramak D. and Henc T. 2008: Określenie wpływu wzbogacalności przerabianych rud na jakość koncentratów miedziowych dla potrzeba optymalizacji górniczo-hutniczego procesu wytwarzania miedzi. Report on the implementation of the study, Krakow, not published

\section{Porównanie wzbogacania głównych minerałów siarczkowych miedzi w warunkach laboratoryj-} nych i przemysłowych w Zakładach Wzbogacania Rud KGHM Polska Miedź S.A.

Cechsztyńskie złoże rud miedzi zalegające na monoklinie przedsudeckiej posiada złożoną budowę geologiczna zarówno pod względem litologicznym jak i mineralogicznym. Znaczna zmienność jakościowa i ilościowa minerałów kruszcowych w złożu jest jednym z czynników determinujących podatność rud miedzi na wzbogacanie flotacyjne w Zakładach Wzbogacania Rud. W celu prognozowania wskaźników wzbogacania $w$ warunkach przemysłowych przeprowadzane sa laboratoryjne eksperymenty flotacyjne wedlug opracowanego algorytmu. W referacie przedstawiono wyniki badań mineralogicznych produktów wzbogacania flotacyjnego jednego $z$ ciagów technologicznych O/ZWR oraz porównano wzbogacanie różnych minerałów siarczkowych miedzi. Wyniki badań laboratoryjnych porównano $z$ wynikami przeprowadzonego równolegle opróbowania ciagu przemystowego. Zaproponowano procedure wyznaczenia równań opisujących krzywe wzbogacalności przemysłowej minerałów siarczkowych miedzi w warunkach O/ZWR.

Stowa kluczowe: minerały siarczkowe miedzi, flotacja, krzywe wzbogacania, indeks skali 